\title{
Deteriorated Indoor Environmental Quality as a Collateral Damage of Present Day Extensive Renovations
}

\author{
Mateja Dovjak $1,{ }^{*}$ - Jan Slobodnik ${ }^{1}$ - Aleš Krainer ${ }^{2}$ \\ ${ }^{1}$ University of Ljubljana, Faculty of Civil and Geodetic Engineering, Slovenia \\ 2Institute of Public and Environmental Health, Slovenia
}

Optimal indoor environmental quality (IEQ) is especially important in every living and working environment with present vulnerable population groups. Especially problematic are educational institutions, where prolonged exposure time of users additionally increases health risks. The present study is focused on the problem of deteriorated IEQ in renovated kindergarten. The problem was critically assessed from the aspects of indoor air quality (IAQ) and energy use. A combination of simulations of the selected IAQ parameters and building energy use was performed for five sets of scenarios, where required and recommended design ventilation rates variated according to Slovenian legislation. Characteristics of actual kindergarten in central Slovenia, renovated in 2016, were used for simulations. Concentrations of $\mathrm{CO}_{2}$ and formaldehyde were calculated in two model playrooms with CONTAM 3.2, whereas building energy use was calculated for two thermal zones of playrooms with Energy Plus 8.0.0. If ventilation in playrooms was designed according to the minimal permissible value (air changes per hour) $\mathrm{ACH}^{0.5,} \mathrm{CO}_{2}$ concentrations exceeded the national maximum permissible level by 2.5 and 3 times, and formaldehyde concentrations was close to the value recommended by World Health Organisation (WHO) and exceeded the level recommended by National Institute for Occupational Safety and Health (NIOSH-CDC) by 4.6 and 4.5 times. All required and recommended design ventilation rates resulted in exceeded values of $\mathrm{CO}_{2}$ above recommendation for category I of IAQ, except the design ventilation rate $55 \mathrm{~m} 3 / \mathrm{h}$ per person. In-line with public health protection measures, relevant information is an aid for recommendation definitions for policies and strategies towards healthier indoor environments as well as for raising awareness about current design practice.

Keywords: kindergarten, energy renovation, air quality, ventilation rate

Highlights

- $\quad$ Our study shows that minimal permissible value, $\mathrm{ACH} 0.5$, results in the highest concentration of $\mathrm{CO}_{2}$ in both playrooms that exceeded the national maximum permissible level for acceptable indoor air quality by 2.5 times and 3 times. Formaldehyde concentrations in both playrooms reached almost the value recommended by WHO and exceeded the level recommended by NIOSH by 4.6 and 4.5 times.

- We proved that only design ventilation rates that take into account the expected number of occupants result in optimal air quality for category I spaces.

- Results show that increase of design ventilation rates from $0.5 \mathrm{ACH}$ to $55 \mathrm{~m} 3 / \mathrm{h}$ per person results in 8.2 times and 6.8 times lower $\mathrm{CO}_{2}$ concentrations and 22.8 times and 17.6 times lower formaldehyde concentrations; on the other hand, building energy use without recuperation was increased by 5.67 times and 6.68 times and with recuperation by 1.81 times and 2.08 times, compared to the reference $0.5 \mathrm{ACH}$ without recuperation.

\section{O INTRODUCTION}

The stock of buildings in Europe is relatively old, with more than $40 \%$ of it built before 1960 and 90 $\%$ before 1990. About $75 \%$ of buildings are energy inefficient and, depending on the individual Member State, $0.4 \%$ to $1.2 \%$ of the stock is renovated each year [1]. From January, 1 st 2014, $3 \%$ of the total floor area of buildings owned by central government must be renovated each year [2]. According to Energy act in the Republic of Slovenia [3], the European requirement is applied also to educational institutions owned by self-governing local communities and public sector.

The present day extensive renovations are going in wrong direction: towards narrow-minded measures with air tightened building, thermally well-insulated envelope, and highly energy efficient mechanical systems. Such non-holistic approach is in fact stimulated by implemented legal requirements on energy efficiency that allow the use of minimal permissible values for ventilation, while other defined requirements and recommendations are as a rule not taken into the consideration. For example, the minimal value of volume air changes per hour $(\mathrm{ACH})$ for working and living spaces at the time when occupants are present is $0.51 / \mathrm{h}$ (Article 8) [4]. Such low ventilation rates have been associated with statistically significant worsening of occupants ' health outcomes [5].

Optimal indoor environmental quality (IEQ) is especially important in every living and working environment with vulnerable population groups. Especially problematic are educational institutions, 
such as kindergartens and schools as well as healthcare facilities, where prolonged exposure times of users increase health risks. Our study focuses on a kindergarten, where several epidemiological studies identify deteriorated indoor air quality (IAQ) as the most problematic field of IEQ. Until now, numerous pollutants have been detected in indoor air of kindergartens, in which primary air quality indicator, $\mathrm{CO}_{2}$ presents the most researched one. AraújoMartins et al. [6] and Mainka and Zajusz-Zubek [7] highlight that $\mathrm{CO}_{2}$ levels often exceed the required and recommended limit values above $1800 \mathrm{mg} / \mathrm{m}^{3}$ (1000 ppm). Especially high concentrations have been associated with low efficiency of ventilation systems. For example, the average measured $\mathrm{CO}_{2}$ in Portuguese daycare centres was $3846 \pm 662 \mathrm{mg} / \mathrm{m}^{3}$ (2137 $\pm 368 \mathrm{ppm})$; in preschool buildings in Poland it was above $1800 \mathrm{mg} / \mathrm{m}^{3}$ (1.000 ppm) [6] and [7]. Butala and Novak [8] performed a study on energy consumption and potential energy savings in 24 school buildings in Slovenia. On average, the total energy consumption per school building was $192 \mathrm{kWh} /$ $\left(\mathrm{m}^{2} \mathrm{a}\right)$, and the maximal concentration of $\mathrm{CO}_{2}$ was above 7198 mg/m³ (4000 ppm). Dovjak and Pajek [9] holistically assessed indoor environmental quality of 24 playrooms in 17 publicly funded children daycare centres in Slovenia. The results showed that the most critical field was the indoor air quality, where in $63 \%$ of playrooms the average $\mathrm{CO}_{2}$ exceeded the required value, $3000 \mathrm{mg} / \mathrm{m}^{3}$ (1667 ppm).

In terms of origin and removal processes, besides $\mathrm{CO}_{2}$ there are also other important pollutants related to IAQ in kindergarten. Study in 5 kindergartens in Hong Kong [10] detected flame retardants, $\mathrm{PM}_{2.5}$, carbonyls and black carbon. The researchers concluded that the evaluated indoor air pollution might present adverse effects to children, where the most problematic were $\mathrm{PM}_{2.5}$ and formaldehyde levels. Study in 25 daycare centres in Seoul [11] evaluated biological (mould and bacteria) and chemical pollutants (formaldehyde, $\mathrm{CO}_{2}, \mathrm{CO}$, and total volatile organic compounds). The concentrations were associated with building age and environmental factors such as ventilation time. Important source of indoor pollution that has to be considered in the design process is outdoor pollution in relation to location sources. Higher concentrations of benzene and $\mathrm{NO}_{2}$ were quantified in 18 schools and kindergartens in Central-Southern Spain located in industrial as well as in rural areas [12]. Additionally, the location of heavy traffic areas were associated with increased exposure to polycyclic aromatic hydrocarbons, detected in indoor air of 27 kindergartens of Sabzevar city, Iran [13].
Educational facilities present $17 \%$ of total floor area and account to $12 \%$ of the final energy use in nonresidential buildings in Europe [14]. The educational facilities in Slovenia accounted to $2131 \mathrm{TJ}$ of the final energy use in 2008 (i.e. $33 \%$ of the total final energy use in buildings of the public sector). Slovenian kindergartens accounted to $255 \mathrm{TJ}$ of the final energy use in 2008, the specific final energy use was $241 \mathrm{kWh} /$ $\mathrm{m}^{2}$ in 2008 [15]. The main reason for high energy use is related to reciprocal effect of imperfections separately on the level of building envelope and systems. To attain optimal IAQ in kindergartens, much higher ventilation rates are needed than in other general environments. Many studies have showed that the increased ventilation rates result in higher ventilation losses and overall building energy use, approximately $2 \%$ to $20 \%$, depending on the specific building and technology parameters [16] and [17]. Since energy crisis in 1970ies, various technologies and systems that can reduce energy use and costs in buildings have been defined. Hekmat et al. [18] showed that total energy use can be reduced by $9 \%$ to $21 \%$ by using mechanical ventilation systems with heat recovery, compared to comparable examined strategies. Deng et al. [19] focused on the ventilation rate of a ground-source heat pump system from the perspective of energy saving and indoor thermal comfort combined. Their findings provide guidelines for reducing power consumption while improving thermal comfort levels. Beside active systems, a passive design strategy, such as wind-driven ventilation, was used to increase indoor air velocity in naturally ventilated buildings [20]. Several authors recommend to define measures from the perspective of energy saving and IEQ combined. Despite scientific findings, current practice is still based on non-holistic measures, in the direction of improvements of building envelope or mechanical systems separately, besides decreased ventilation rates.

This study is focused on the problem of deteriorated IEQ in renovated kindergartens in Slovenia. The main purpose of our study was to critically assess the relevant problem with comparative analysis of indoor air quality and energy use. A combination of simulations of selected parameters of IAQ and building energy use was performed for five sets of scenarios, where design ventilation rates variated according to national legislation [4]. Actual kindergarten in central Slovenia, renovated in 2016, was used for simulations. Concentrations of $\mathrm{CO}_{2}$ and formaldehyde were calculated in two model playrooms (age groups 1 and 2) with CONTAM version 3.2. Annual energy use for heating (i.e. building net energy for heating) was calculated for two thermal 
zones in playrooms with Energy Plus 8.8.0. Research questions were: 1 . What is the impact of various design ventilation rates on $\mathrm{CO}_{2}$ and formaldehyde concentrations? 2. How do design ventilation rates affect building energy use? 3 . Which is the optimal design ventilation rate according to target users, room purpose and its specifics, resulting in optimal IEQ and simultaneously minimal possible energy use? Inline with public health protection measures, relevant information is an aid for recommendation definitions for policies and strategies towards healthier indoor environments as well as for raising awareness in current design practice.

\section{METHODS}

Three-dimensional model of the selected parts of an actual building was established according to the provided floor plans and technical description of the building. It is a multi-story building $\left(4345.4 \mathrm{~m}^{3}\right.$, $1289.6 \mathrm{~m}^{2}$ ) that consists of a ground floor, first floor and attic. Story height varies between $2.5 \mathrm{~m}$ to $3.1 \mathrm{~m}$. Slope degree of the pitch roof is $28 \%$.

Exterior wall of the building is composed of reinforced concrete with polystyrene thermal insulation and façade plaster $\left(U_{\text {wall }} 0.60 \mathrm{~W} /\left(\mathrm{m}^{2} \mathrm{~K}\right)\right)$. Ventilated roof is composed of reinforced concrete, mineral wool thermal insulation and covered with Al sheet $\left(U_{\text {roof }} 0.16 \mathrm{~W} /\left(\mathrm{m}^{2} \mathrm{~K}\right)\right)$. Concrete slab floor construction is composed of polystyrene sound insulation, screed and wooden flooring $\left(U_{\text {floor }} 0.96 \mathrm{~W} /\right.$ $\left.\left(\mathrm{m}^{2} \mathrm{~K}\right)\right)$. Windows are south oriented triple glazing with PVC frame (window area $11 \mathrm{~m}^{2}$, wall area 18.1 $\mathrm{m}^{2}$, WWR $0.60 \mathrm{~m}^{2}, U_{\text {window }} 1.06 \mathrm{~W} /\left(\mathrm{m}^{2} \mathrm{~K}\right)$ ).

For the simulation of IAQ indicators two different ventilation zones (i.e. playroom A for age group 2: $42.0 \mathrm{~m}^{2}, 126.84 \mathrm{~m}^{3}$; playroom B for age group 1: 32.5 $\mathrm{m}^{2}, 98.80 \mathrm{~m}^{3}$ ) were selected. For simulation of energy use two thermal zones were considered, located at the ground floor (i.e. six playrooms for age group 2: 252.0 $\mathrm{m}^{2}, 761.0 \mathrm{~m}^{3}$ ), and first floor (i.e. six playrooms for age group 1: $195.0 \mathrm{~m}^{2}, 592.8 \mathrm{~m}^{3}$ ) (Fig. 1, Table 1).
Table 1. Characteristics of analysed model playrooms

\begin{tabular}{|c|c|c|}
\hline Characteristics & $\begin{array}{c}\text { Playroom A } \\
\text { (3 to } 6 \text { years) }\end{array}$ & $\begin{array}{l}\text { Playroom B } \\
\text { (1 to } 2 \text { years) }\end{array}$ \\
\hline$V_{z}\left[\mathrm{~m}^{3}\right]$ & 126.84 & 98.80 \\
\hline$A_{z}\left[\mathrm{~m}^{2}\right]$ & 42.0 & 32.50 \\
\hline$A_{\text {window }}\left[\mathrm{m}^{2}\right]$ & 69.6 & 69.6 \\
\hline$W W R$ & 0.54 & 0.55 \\
\hline $\begin{array}{l}U_{\text {window }} \\
{\left[\mathrm{W} /\left(\mathrm{m}^{2} \mathrm{~K}\right)\right]}\end{array}$ & 1.06 & 1.06 \\
\hline$\tau_{\mathrm{aov}}[-]$ & 0.46 & 0.46 \\
\hline $\begin{array}{l}U_{\text {wall }} \\
{\left[\mathrm{W} /\left(\mathrm{m}^{2} \mathrm{~K}\right)\right]}\end{array}$ & 0.60 & 0.60 \\
\hline $\begin{array}{l}\text { Infliltration } \\
{[1 / \mathrm{h}]}\end{array}$ & 0.30 & 0.30 \\
\hline$V_{\mathrm{in}, \mathrm{d}}\left[\mathrm{m}^{3} / \mathrm{h}\right]$ & 250 & 250 \\
\hline$V_{\text {out,d }}\left[\mathrm{m}^{3} / \mathrm{h}\right]$ & 250 & 250 \\
\hline $\begin{array}{l}\text { Furniture load } \\
{\left[\mathrm{m}^{2}\right] \text {, }} \\
\text { No. pieces }\end{array}$ & $\begin{array}{c}\left.11.25 \mathrm{~m}^{2} \text { ( } 5 \text { tables }\right), \\
26 \text { chairs, } \\
12 \mathrm{~m}^{2} \text { (1 bookcase), } \\
11 \mathrm{~m}^{2} \text { (5 cabinets) }\end{array}$ & $\begin{array}{c}6.75 \mathrm{~m} 2 \text { ( } 3 \text { tables), } \\
16 \text { chairs, } \\
12 \mathrm{~m}^{2} \text { ( } 1 \text { bookcase), } \\
11 \mathrm{~m}^{2} \text { (5 cabinets) }\end{array}$ \\
\hline $\begin{array}{l}\text { Product } \\
\text { specific } \\
\text { emission } \\
\text { [mg/h] [21] }\end{array}$ & $\begin{array}{c}0.94 \mathrm{mg} / \mathrm{h} \text { (5 tables) } \\
3.25 \mathrm{mg} / \mathrm{h} \text { (chairs) } \\
1.00 \mathrm{mg} / \mathrm{h} \text { (1 bookcase) } \\
0.69 \mathrm{mg} / \mathrm{h} \text { (5 cabinets) }\end{array}$ & $\begin{array}{c}0.50 \mathrm{mg} / \mathrm{h} \text { (3 tables) } \\
2.25 \mathrm{mg} / \mathrm{h} \text { (chairs) } \\
1.00 \mathrm{mg} / \mathrm{h} \text { ( } 1 \text { bookcase) } \\
0.69 \mathrm{mg} / \mathrm{h} \text { ( } 5 \text { cabinets })\end{array}$ \\
\hline
\end{tabular}

$V_{z}$ zone volume, $A_{z}$ net occupant floor area of the ventilation zone, $A_{\text {window }}$ window area, $W W R$ window to wall ratio, $U_{\text {window }}$ thermal transmittance of window, $\tau_{\text {ao v }}$ glass visible transmittance, $U_{\text {wall }}$ thermal transmittance of wall,

$V_{\text {in,d }}$ designed inlet air volume flow, $V_{\text {out,d }}$ designed outlet air volume

\subsection{Simulation of Indoor Air Quality}

Indoor air quality was analysed by a multizone indoor air quality and ventilation analysis program CONTAM 3.2 [22]. It enables the calculation of contaminant concentrations in model room by various airflow rates and by a variety of processes including emissions from building materials, human metabolism and personal exposure. $\mathrm{CO}_{2}$ and formaldehyde concentrations $\left(\mathrm{CO}_{2}, \mathrm{CH}_{2} \mathrm{O}\right)$ were calculated by steady state method in two model playrooms: playroom $\mathrm{A}$ for age group 2 (ground floor); playroom $\mathrm{B}$ for age group 1 (first floor) (Table 2). $\mathrm{CO}_{2}$ and $\mathrm{CH}_{2} \mathrm{O}$ were presented in units $\mathrm{mg} /$ $\mathrm{m}^{3}$ and $\mathrm{ppm}$, where conversion equation is based on

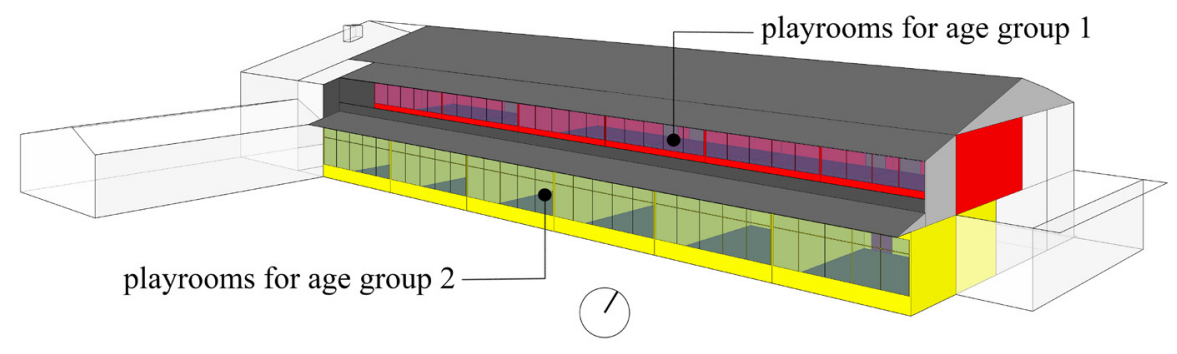

Fig. 1. Three-dimensional model with analysed ventilation zones and thermal zones 
$25^{\circ} \mathrm{C}$ and $101.3 \mathrm{kPa}$. Background outdoor $\mathrm{CO}_{2}, 719.8$ $\mathrm{mg} / \mathrm{m}^{3}$ (400 ppm) were assumed for calculations.

Validation of the model was based on an actual set of measurements performed in a classically built and prefabricated kindergarten, both subunits of our analysed building (i.e. six measuring days, time periods approximately $8: 30$ to $10: 30,10: 00$ to 12:00). The evaluated parameters in two selected playrooms (age group 2) were: number of occupants and their activity, status of window and its opening time, ventilation rate and concentration of $\mathrm{CO}_{2}$ in 10 minutes time step. Beside measured levels, $\mathrm{CO}_{2}$ was calculated in both playrooms for every time step according to the real time influential evaluated parameters.

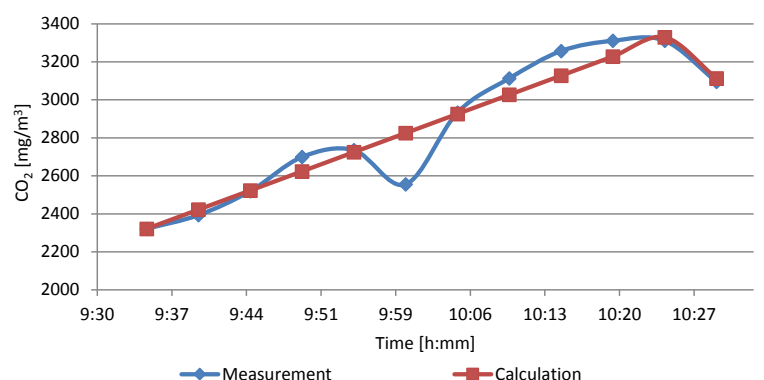

Fig. 2. Measured and calculated $\mathrm{CO}_{2}$ for measuring day No.6, playroom in classically built kindergarten

$\mathrm{CO}_{2}$ metabolic generation rate coefficients variated according to the actual activity of children. Fig. 2 presents the comparison between measured and calculated $\mathrm{CO}_{2}$ concentration in playroom of the classically built kindergarten for one measuring day. 9 children and 2 teachers were present during our measurement. In the time period 9:35 to $10: 30,0.24$ $\mathrm{L} / \mathrm{min} \mathrm{CO}_{2}$ generation rate was assumed. Ventilation rate was $19.8 \mathrm{~m}^{3} / \mathrm{h}(8: 30$ to $10: 25)$ and $118 \mathrm{~m}^{3} / \mathrm{h}$ $(10: 25$ to $10: 30)$.

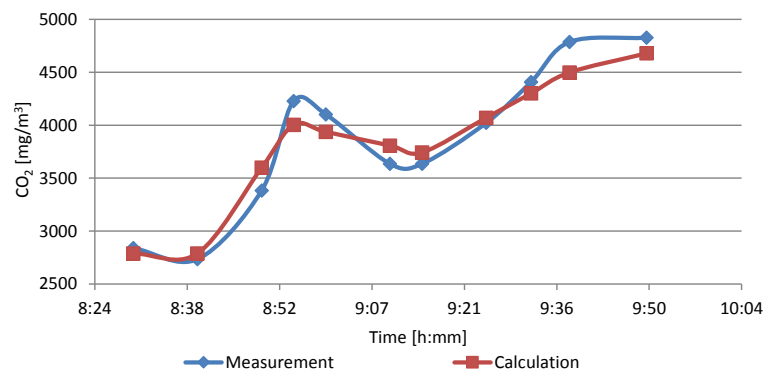

Fig. 3. Measured and calculated $\mathrm{CO}_{2}$ for measuring day No. 3, playroom in prefabricated kindergarten

Fig. 3 presents the comparison between measured and calculated $\mathrm{CO}_{2}$ concentration in the prefabricated playroom for one measuring day. 15 children and 2 teachers were present during our measurement. In the time period 8:30 to $8: 50,0.35 \mathrm{~L} / \mathrm{min} \mathrm{CO}_{2}$ generation rate was assumed and in the time period 8:50 to 9:50, $0.15 \mathrm{~L} / \mathrm{min}$. In the time periods $8: 30$ to $8: 55$ and $9: 25$ to $9: 50$ the ventilation rate was $28.2 \mathrm{~m}^{3} / \mathrm{h}$ and for $9: 00$ to $9: 15,44 \mathrm{~m}^{3 / \mathrm{h}}$ (small window opened).

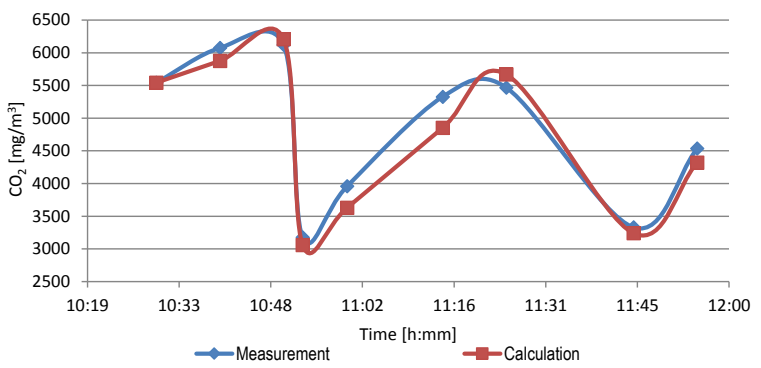

Fig. 4. Measured and calculated $\mathrm{CO}_{2}$ concentration for measuring day No. 1, playroom in classically built kindergarten

Fig. 4 presents the comparison between measured and calculated $\mathrm{CO}_{2}$ concentration in playroom of the classically built kindergarten for one measuring day. 14 children and 2 teachers were present during our measurement $\left(0.24 \mathrm{~L} / \mathrm{min} \mathrm{CO}_{2}\right.$ generation rate). In the time periods $10: 53$ to $11: 00$ and $11: 45$ to $11: 55$, maximal ventilation rate $810.0 \mathrm{~m}^{3} / \mathrm{h}$ was attained, due to opened windows and door (no children, $0 \mathrm{~L} / \mathrm{min}$ $\mathrm{CO}_{2}$ generation rate). The average ventilation rate was $256 \mathrm{~m}^{3} / \mathrm{h}$.

Characteristics of model playrooms and subjects are presented in Tables 1 and 2, respectively.

Table 2. Characteristics of subjects in analysed model playrooms

\begin{tabular}{lcc}
\hline $\begin{array}{l}\text { Model playroom } \\
\text { /subject characteristic }\end{array}$ & Playroom A & Playroom B \\
\hline $\begin{array}{l}\text { No. of subjects } \\
\text { 24 children } \\
\text { 2 educators }\end{array}$ & $\begin{array}{c}\text { 14 toddlers } \\
\text { 2 educators }\end{array}$ \\
\hline Age of children [years] & 3 to 6 & 1 to 2 \\
\hline $\begin{array}{l}\mathrm{CO}_{2} \text { metabolic emission } \\
\text { rate [L/s] [23] }\end{array}$ & Children: 0.0029, Educators: 0.0052 \\
\hline $\mathrm{M}_{\text {children }}\left[\mathrm{W} / \mathrm{m}^{2}\right][24]$ & Sitting, crawling: 78.5, Sleeping: 46.6 \\
\hline $\mathrm{A}_{\mathrm{du}}\left[\mathrm{m}^{2}\right]$ & 0.69 & 0.51 \\
\hline
\end{tabular}

Detailed methodology and results are described in Dovjak et al. [25] and Pirc [26]. Results of our measurements showed nearly complete correlation with calculated $\mathrm{CO}_{2}$ for all measuring days. Measured average $\mathrm{CO}_{2}$ deviated from calculated values by 11.8 $\mathrm{mg} / \mathrm{m}^{3}$ in prefabricated kindergarten and $12.6 \mathrm{mg} / \mathrm{m}^{3}$ in classical built kindergarten.

To answer the research questions, we performed five sets of scenarios, where the required and 
Table 3. List of required and recommended design ventilation rates for playrooms in kindergarten [4]

\begin{tabular}{|c|c|c|c|}
\hline $\begin{array}{c}\text { Sets of } \\
\text { scenarios }\end{array}$ & $\begin{array}{l}\text { Required and recommended design ventilation } \\
\text { rate }\end{array}$ & $\begin{array}{l}\text { Playroom A: calculated required and } \\
\text { recommended outdoor airflow }\end{array}$ & $\begin{array}{l}\text { Playroom B: calculated required and } \\
\text { recommended outdoor airflow }\end{array}$ \\
\hline 1 & Minimal ACH: 0.5/h & $63.42 \mathrm{~m} 3 / \mathrm{h}$ & $49.40 \mathrm{~m} 3 / \mathrm{h}$ \\
\hline 2 & Minimal volume of air for person: $8.7 \mathrm{~m} 3 / \mathrm{hm}^{2}$ & $365.4 \mathrm{~m} 3 / \mathrm{hm}^{2}(2.9 \mathrm{ACH})$ & $282.8 \mathrm{~m}^{3} / \mathrm{hm}^{2}(2.9 \mathrm{ACH})$ \\
\hline 3 & Minimal outdoor air intake: 15 m³/h per person & $390.0 \mathrm{~m} 3 / \mathrm{h}(3.1 \mathrm{ACH})$ & $240.0 \mathrm{~m}^{3} / \mathrm{h}(2.4 \mathrm{ACH})$ \\
\hline 4 & Minimal air volume: $10.1 \mathrm{~m} 3 / \mathrm{hm}^{2}$ & $424.2 \mathrm{~m} 3 / \mathrm{h}(3.3 \mathrm{ACH})$, & $328.3 \mathrm{~m} 3 / \mathrm{h}(3.3 \mathrm{ACH})$ \\
\hline 5 & Air volume: $55 \mathrm{~m} 3 / \mathrm{h}$ per person & $1430.0 \mathrm{~m}^{3} / \mathrm{h}(11.3 \mathrm{ACH})$ & 880.0 m³/h (8.9 ACH) \\
\hline
\end{tabular}

recommended design ventilation rates varied according to the values from national legislation [4] (Table 3).

To calculate $\mathrm{CH}_{2} \mathrm{O}$, we took into account typical wooden furnishing in compliance with $\mathrm{E} 1$ class $\left(0.124 \mathrm{mg} / \mathrm{m}^{3}\right)$ [27]. According to data [21] and [28], we assumed product specific emissions (Table 1). The calculated $\mathrm{CO}_{2}$ and $\mathrm{CH}_{2} \mathrm{O}$ were compared to the required and recommended values. According to national Rules [4], the permissible value of $\mathrm{CO}_{2}$ in indoor air is $3000 \mathrm{mg} / \mathrm{m}^{3}$ (1667 ppm). Recommended $\mathrm{CO}_{2}$ concentration for the design and assessment of energy performance in buildings with spaces occupied by vulnerable population groups - category I is $630 \mathrm{mg} / \mathrm{m}^{3}$ (350 ppm) above background outdoor concentration [29]. ANSI/ASHRAE Standard 62.1 [30] defines that $\mathrm{CO}_{2}$ concentration should not exceed $2500 \mathrm{ppm}\left(4499 \mathrm{mg} / \mathrm{m}^{3}\right)$, while $1000 \mathrm{ppm}$ is the recommended value $\left(1800 \mathrm{mg} / \mathrm{m}^{3}\right)$. A short-term (30 min) guideline of $0.1 \mathrm{mg} / \mathrm{m}^{3}(0.081 \mathrm{ppm}) \mathrm{CH}_{2} \mathrm{O}$ is recommended by World Health Organisation, WHO [31]. National Institute for Occupational Safety and Health [32] recommends $0.0196 \mathrm{mg} / \mathrm{m}^{3}(0.016 \mathrm{ppm})$ time weighted average (TWA) exposure.

\subsection{Simulation of Energy Use}

Energy use was simulated for five sets of scenarios with energy analysis and thermal load simulation program EnergyPlus 8.8.0 [33]. The building model was created by graphical user interface OpenStudio. Building and mechanical system configurations and conditions were defined according to actual data.

Energy indicators were calculated for thermal zones of six playrooms for age group 1 (i.e. set point temperature, $24^{\circ} \mathrm{C}$ ) and six playrooms for age group $2\left(22^{\circ} \mathrm{C}\right)$ : overall building energy use for heating, i.e. building net energy for heating $\left(\mathrm{kWh} /\left(\mathrm{m}^{2} \mathrm{a}\right)\right)$, transmission heat losses $\left(\mathrm{kWh} /\left(\mathrm{m}^{2} \mathrm{a}\right)\right)$, ventilation heat losses $\left(\mathrm{kWh} / \mathrm{m}^{2} \mathrm{a}\right)$, solar heat gains $\left(\mathrm{kWh} /\left(\mathrm{m}^{2} \mathrm{a}\right)\right)$ and internal heat gains $\left(\mathrm{kWh} /\left(\mathrm{m}^{2} \mathrm{a}\right)\right)$. Calculation was based on yearly method. Additionally, the increase ratio of ventilation heat losses was calculated for five sets of scenarios with and without recuperation. It presented the ratio of heat losses by ventilation for considered set of scenarios regarding the reference design ventilation rate, $0.5 \mathrm{ACH}$, without recuperation.

\section{RESULTS}

\subsection{Air Quality}

Fig. 5 presents the calculated $\mathrm{CO}_{2}$ in model playrooms $\mathrm{A}$ and $\mathrm{B}$ for five sets of scenarios, where the required and recommended design ventilation rates varied according to national legislation. The calculated $\mathrm{CO}_{2}$ includes background outdoor concentration $719.8 \mathrm{mg} /$ $\mathrm{m}^{3}(400 \mathrm{ppm})$. In playroom $\mathrm{A}$, the highest $\mathrm{CO}_{2}$ was reckoned up in scenario 1 with ACH $0.5(8891 \mathrm{mg} /$ $\mathrm{m}^{3}, 4941 \mathrm{ppm}$ ) (Fig. 5), while the lowest $\mathrm{CO}_{2}$ was in scenario 5 with $55 \mathrm{~m} / \mathrm{h}$ per person $\left(1082 \mathrm{mg} / \mathrm{m}^{3}, 601\right.$ $\mathrm{ppm})$. Similar findings were obtained in playroom $\mathrm{B}$, scenario 1 , where ACH 0.5 resulted in the highest $\mathrm{CO}_{2}\left(7408 \mathrm{mg} / \mathrm{m}^{3}, 4116 \mathrm{ppm}\right)$. In both playrooms for scenario 1 with $\mathrm{ACH} 0.5$, the calculated $\mathrm{CO}_{2}$ exceeded the required and recommended values [4], [29] and [30] by 3 and 2.5 times.

Higher design ventilation rates $\left(15 \mathrm{~m}^{3 / h}\right.$ per person, $10.1 \mathrm{~m}^{3} /\left(\mathrm{hm}^{2}\right), 55 \mathrm{~m}^{3} / \mathrm{h}$ per person, $\left.8.7 \mathrm{~m}^{3} /\left(\mathrm{hm}^{2}\right)\right)$ resulted in lower $\mathrm{CO}_{2}$. Only design ventilation rates that take into account the expected number of occupants ( $55 \mathrm{~m}^{3} / \mathrm{h}$ per person) resulted in optimal air quality for category I spaces [29].

Similar findings can be obtained in case of calculated $\mathrm{CH}_{2} \mathrm{O}$. The highest $\mathrm{CH}_{2} \mathrm{O}$ was calculated in scenario 1 with ACH 0.5 (playroom A: $0.091 \mathrm{mg} / \mathrm{m}^{3}$, $0.074 \mathrm{ppm}$; playroom B: $0.088 \mathrm{mg} / \mathrm{m}^{3}, 0.072 \mathrm{ppm}$ ) (Fig. 6). The lowest $\mathrm{CO}_{2}$ was calculated in scenario 5 with $55 \mathrm{~m}^{3} / \mathrm{h}$ per person (playroom A: $0.004 \mathrm{mg} / \mathrm{m}^{3}$, 0.003 ppm; playroom B: $\left.0.005 \mathrm{mg} / \mathrm{m}^{3}, 0.004 \mathrm{ppm}\right)$. If ventilation in a playroom is designed according to the minimal permissible value $\mathrm{ACH} 0.5$, the calculated $\mathrm{CH}_{2} \mathrm{O}$ almost reached the values recommended by WHO [31] and exceeded the level recommended by 


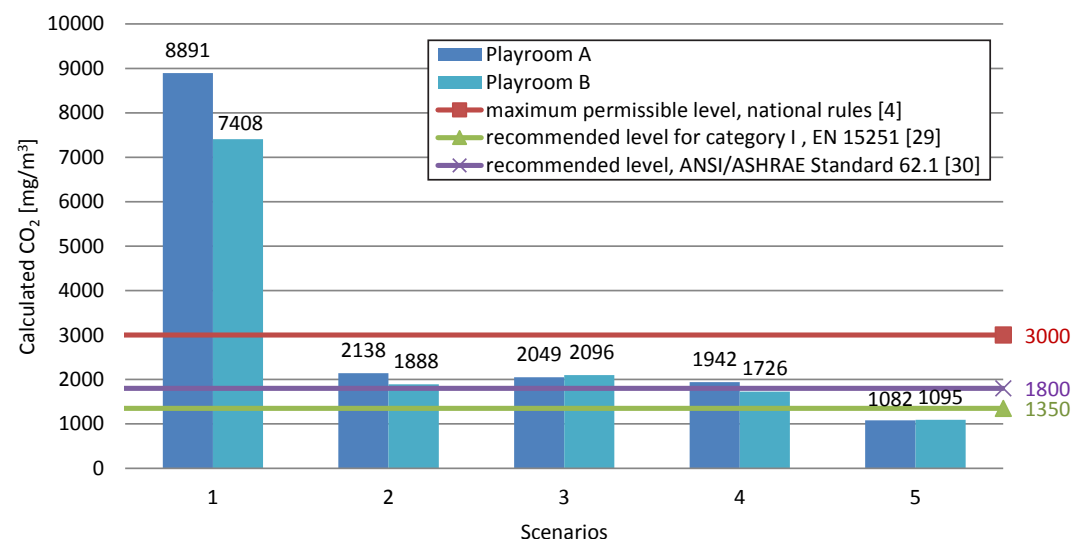

Fig. 5. Calculated $\mathrm{CO}_{2}\left[\mathrm{mg} / \mathrm{m}^{3}, \mathrm{ppm}\right]$ in analysed model playrooms for five sets of scenarios

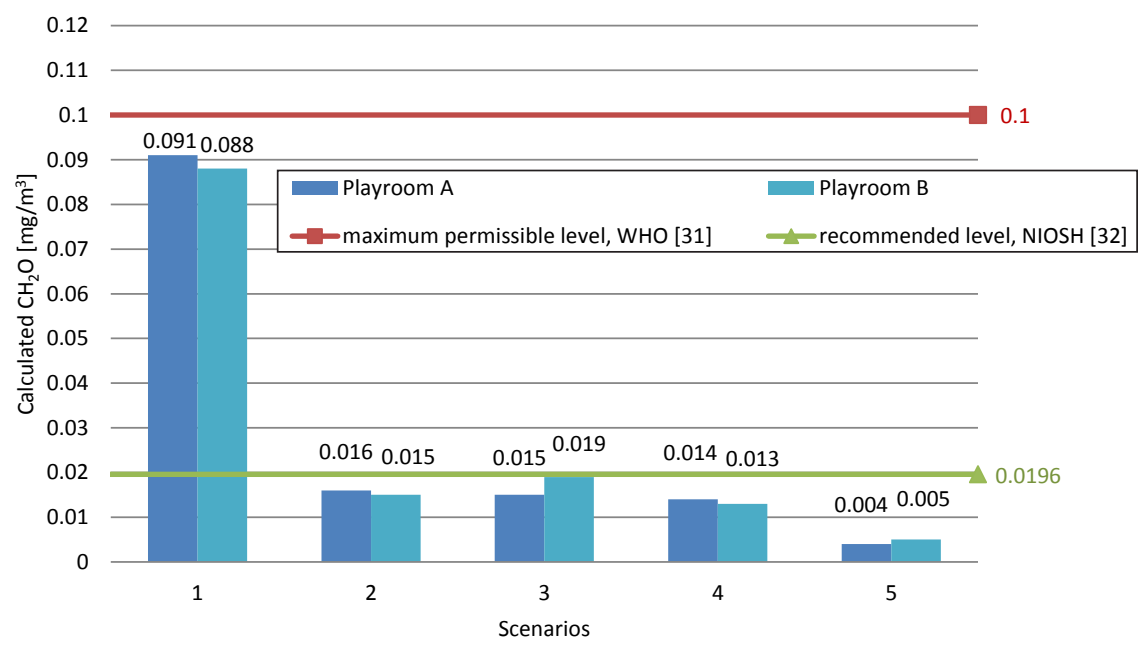

Fig. 6. Calculated $\mathrm{CH}_{2} \mathrm{O}\left[\mathrm{mg} / \mathrm{m}^{3}, \mathrm{ppm}\right]$ in analysed model playrooms for five sets of scenarios

NIOSH by 4.6 (playroom A) and 4.5 times (playroom B) [32].

\subsection{Energy Use}

Table 4 presents the calculated values of annual energy use for heating, heat gains and losses for two thermal zones and reference scenario $1(0.5 \mathrm{ACH})$.

As it was shown in the analysis of IAQ indicators, the design ventilation rate $55 \mathrm{~m}^{3} / \mathrm{h}$ per person (scenario 5) resulted in the highest level of IAQ in both playrooms. Consequently, this resulted in proportionally higher heat losses by ventilation $285.76 \mathrm{kWh} /\left(\mathrm{m}^{2} \mathrm{a}\right.$ ) (or overall energy use for heating $\left.325.50 \mathrm{kWh} /\left(\mathrm{m}^{2} \mathrm{a}\right)\right)$ in playroom age group 1 and $292.99 \mathrm{kWh} /\left(\mathrm{m}^{2} \mathrm{a}\right)$ (or overall energy use 285.40 $\left.\mathrm{kWh} /\left(\mathrm{m}^{2} \mathrm{a}\right)\right)$ in playroom age group 2 . Increase ratio between scenarios 5 and 1 is 5.67 and 6.68 (Table 5). However, in case of application of recuperation in scenario 5, the heat losses for ventilation were 91.28 $\mathrm{kWh} /\left(\mathrm{m}^{2} \mathrm{a}\right)$ (or overall energy use $131.40 \mathrm{kWh} /\left(\mathrm{m}^{2} \mathrm{a}\right)$ ) in playrooms age group 1 and $91.10 \mathrm{kWh} /\left(\mathrm{m}^{2} \mathrm{a}\right.$ ) (or overall energy use $\left.90.10 \mathrm{kWh} /\left(\mathrm{m}^{2} \mathrm{a}\right)\right)$ in playroom age group 2 . Therefore, the increase ratio was only 1.81 and 2.08 compared to scenario $1,0.5 \mathrm{ACH}$ without recuperation.

The application of recuperation resulted in minimal change in heat losses for ventilation between scenarios 4 and 5 , which was $31.40 \mathrm{kWh} /\left(\mathrm{m}^{2} \mathrm{a}\right)$ for playroom age group 1 and $41.50 \mathrm{kWh} /\left(\mathrm{m}^{2} \mathrm{a}\right)$ for playroom age group 2, with increase ratios 1.60 and 1.84 , respectively.

Therefore, the determination of required design ventilation rate must provide primarily, the highest level of IAQ and secondly lower energy use. Minimisation of energy use should be achieved besides by strict hygienic requirements and maintenance also with local recuperation and other efficient systems. Savings 
Table 4. Annual energy use for heating, components of heat gains and losses $\left[\mathrm{kWh} /\left(\mathrm{m}^{2} \mathrm{a}\right)\right]$ for thermal zones and scenario 1

\begin{tabular}{cccccc}
\hline Thermal zone & Energy use for heating & \multicolumn{2}{c}{ Heat gains $\left[\mathrm{kWh} /\left(\mathrm{m}^{2} \mathrm{a}\right)\right]$} & \multicolumn{2}{c}{ Heat losses $\left[\mathrm{kWh} /\left(\mathrm{m}^{2} \mathrm{a}\right)\right]$} \\
\cline { 3 - 6 } & {$\left[\mathrm{kWh} /\left(\mathrm{m}^{2} \mathrm{a}\right)\right]$} & Interior & Solar & Transmission & Ventilation \\
\hline Playrooms age group 1 & 77.50 & 28.20 & 10.70 & 80.10 & 50.40 \\
\hline Playrooms age group 2 & 43.30 & 58.30 & 39.00 & 118.9 & 43.90 \\
\hline
\end{tabular}

Table 5. Annual heat loss by ventilation for thermal zone of playrooms for five sets of scenarios $\left[\mathrm{kWh} /\left(\mathrm{m}^{2} \mathrm{a}\right)\right]$

\begin{tabular}{ccccc}
\hline Thermal zone $/$ & \multicolumn{2}{c}{ Playrooms age group 1 } & \multicolumn{2}{c}{ Playrooms age group 2 } \\
\cline { 2 - 5 } Sets of scenarios & Heat loss by ventilation $\left[\mathrm{kWh} /\left(\mathrm{m}^{2} \mathrm{a}\right)\right]$ & Increase ratio* $[-]$ & Heat loss by ventilation $\left[\mathrm{kWh} /\left(\mathrm{m}^{2} \mathrm{a}\right)\right]$ & Increase ratio* $\left.^{*}-\right]$ \\
\hline 1 & 50.40 & 1.00 & 43.86 & 1.00 \\
\hline 2 & 117.69 & 2.34 & 100.70 & 2.30 \\
\hline 3 & 103.68 & 2.06 & 105.31 & 2.40 \\
\hline 4 & 128.89 & 2.56 & 109.92 & 2.51 \\
\hline 5 & 285.76 & 5.67 & 292.99 & 6.68 \\
\hline
\end{tabular}

* According to the reference design ventilation rate $(0.5 \mathrm{ACH})$ without recuperation.

with achieving physiological minimums should not be allowed!

\section{DISCUSSION}

The problem of deteriorated IEQ in renovated public and residential buildings has been highlighted in epidemiological studies [6], [7] and [34], as well as pointed out by building users. Poor indoor air quality presents one of the most expanded indicator of inadequate indoor environment and is recognized as the leading health risk factor in built environment. WHO [35] reported that 4.3 million people a year die because of the exposure to indoor air pollution.

Decision making in current design practice is often directed towards reducing energy losses through the instrument of minimal permissible values of ventilation rate. We have critically assessed the impact of variations in design ventilation rate on the selected air quality indicators, $\mathrm{CO}_{2}$ and $\mathrm{CH}_{2} \mathrm{O}$. Concentration of a main bioeffluent and indicator of air quality $\mathrm{CO}_{2}$, varies according to the rates of occupancy and design ventilation. The highest concentration was in playroom A $\left(8891 \mathrm{mg} / \mathrm{m}^{3}, 4941 \mathrm{ppm}\right)$ and playroom B $\left(7408 \mathrm{mg} / \mathrm{m}^{3}, 4116 \mathrm{ppm}\right)$ with scenario $1,0.5$ $\mathrm{ACH}$. According to national rules, the calculated $\mathrm{CO}_{2}$ exceeded the required value of $3000 \mathrm{mg} / \mathrm{m}^{3}$ (1667 ppm) by 3 times (in playroom A) and 2.5 times (in playroom B). However, Bakó-Biró et al. [36] reported that even lower levels of $\mathrm{CO}_{2}$ concentrations, compared to these required concentrations, may lead to occupant dissatisfaction and decreased productivity. In order to protect particularly vulnerable population groups, optimal and not the lowest permitted values for acceptable indoor air quality have to be used.
Thus, recommended $\mathrm{CO}_{2}$ concentration for category I spaces occupied by vulnerable population groups is $630 \mathrm{mg} / \mathrm{m}^{3}(350 \mathrm{ppm})$ above background outdoor concentration [29]. All required and recommended design ventilation rates resulted in values of $\mathrm{CO}_{2}$ above recommendation, except $55 \mathrm{~m}^{3} / \mathrm{h}$ per person.

In the European Union, formaldehyde is classified under category 1B carcinogen [37]. Acute and chronic inhalation exposure to formaldehyde in humans can result in eye, nose and throat irritation, respiratory symptoms, exacerbation of asthma, and sensitization [31]. Our study highlighted that design of buildings on minimal permissible values $0.5 \mathrm{ACH}$ results in concentration that reaching almost the limit value for formaldehyde $0.1 \mathrm{mg} / \mathrm{m}^{3}(0.081 \mathrm{ppm})$ [31] in both playrooms, which can cause irritation of sensitive people after $30 \mathrm{~min}$ of exposure [31]. Additionally, $\mathrm{CH}_{2} \mathrm{O}$ exceeded the recommended limit level by NIOSH [32] by 4.6 (playroom A) and 4.5 times (playroom B). Besides that, the calculated $\mathrm{CH}_{2} \mathrm{O}$ at 0.5 $\mathrm{ACH}$ reaches the odour threshold for formaldehyde, $0.0614 \mathrm{mg} / \mathrm{m}^{3}$ to $1.23 \mathrm{mg} / \mathrm{m}^{3}$ (0.05 ppm to $1.0 \mathrm{ppm}$ ). According to ANSI/ASHRAE Standard 62.1-2010 [38], the calculated $\mathrm{CH}_{2} \mathrm{O}$ exceeded the concentration of $0.0331 \mathrm{mg} / \mathrm{m}^{3}(0.027 \mathrm{ppm}, 8 \mathrm{~h}, \mathrm{CARB})$, which might cause irritation in sensitive individuals. Reaching $0.0614 \mathrm{mg} / \mathrm{m}^{3}$ to $1.29 \mathrm{mg} / \mathrm{m}^{3}$ (0.05 ppm to $1.05 \mathrm{ppm})$ might lead to neurophysiological health effects [39].

Despite, current design practice, European standards provide different approach [40]. For example, EN 15251 [29] defines the design criteria for I-IV categories of indoor environment. The required ventilation rates are based on health and comfort criteria and expressed in three ways: 1 . calculated 
for people and building components, 2. calculated per person or per square meter floor area or 3. based on a mass balance and $\mathrm{CO}_{2}$ level. Similarly, SIST CR 1752 [41] that presents the basic standard for the national Rules on ventilation [4] defines the design criteria for A-C categories. Moreover, several researchers concluded that optimal ventilation rates that result in the decreased health related outcomes (i.e. expressed per person), are much higher than those recommended in standards or required by law. For example, literature review of 41 studies [5] showed that ventilation rates below $10 \mathrm{~L} / \mathrm{s}$ per person in office buildings were associated with statistically significant worsening in one or several health or perceived air quality outcomes. Carrer et al. [42] estimated the lowest ventilation rates with no adverse effects for respiratory symptoms, asthma or allergy symptoms, airborne infectious diseases or acute health symptoms, to be about $6 \mathrm{~L} / \mathrm{s}$ to $7 \mathrm{~L} / \mathrm{s}$ per person. In terms of effects on short-term absence rates and performance and learning, these minimum rates are much higher, ranging from $16 \mathrm{~L} / \mathrm{s}$ to $24 \mathrm{~L} / \mathrm{s}$ per person.

Standards often guide designers as follows: "When national regulations do not decide it, the designer shall make his own decision and report it". And consequently, due to economic and energetic pressures, they often select lower levels, which might "work" in general environments (i.e. living room, offices), but are not accepted in other indoor environments with vulnerable population groups (i.e. kindergartens), where the number of users and activity might be dynamically changed. Unfortunately, such biased approach is reflected in collateral damage, the attainment of physiological minimums and its negative health outcomes. We reviewed these problems in current design practice, as reported by users, and they present the motive of our research.

As it was presented, in the design of ventilation systems for educational institutions, special attention is needed, due to present vulnerable population groups. Required design ventilation rates have to be defined in-line with scientific findings that support higher ventilation rates to attain optimal indoor air quality. To attain energy efficiency, deep renovation is needed, from building envelope [43] to mechanical systems based on renewable energy sources [44]. Special attention has to be paid to thermal comfort that should be based on exergy analyses approach [45], which takes into account location characteristics and user specifics [46]. Our study evaluated the effect of recuperators. It showed the decreased energy use for heating from $12 \%(0.5 \mathrm{ACH})$ to $68 \%(8.9 \mathrm{ACH}$ and $11.3 \mathrm{ACH})$, which is comparable to other studies [17].
Other researchers [17] to [19] recommend combination of passive and active systems in order to achieve energy efficiency without deterioration of IEQ.

\section{CONCLUSIONS}

Building renovation should be directed towards attaining healthy and incentive indoor environments particularly for vulnerable population groups. This approach is highlighted also in new Directive (EU) 2018/844 [1]: "Better performing buildings provide higher comfort levels and wellbeing for their occupants and improve health by reducing mortality and morbidity from a poor indoor climate. Adequately heated and ventilated dwellings alleviate negative health impacts caused by dampness, particularly amongst vulnerable groups such as children and the elderly and those with pre-existing illnesses".

Unfortunately, besides the treated issues of deteriorated IAQ, there is also a problem in current design practice that the actual number or children and educators in a playroom is much higher than the defined number in the building permit. Irrespectively, the selected calculation model for the design of ventilation, i.e. $\mathrm{ACH}$, and $\mathrm{m}^{3} /\left(\mathrm{hm}^{2}\right)$ might results in sufficient outdoor airflow per $\mathrm{m}^{2}$, but not per person. This can cause problematic deterioration of IAQ.

To maintain high level of IAQ it is necessary to implement integral interventions, supported by national policies and strategies. Healthy indoor environment may encourage a higher renovation rate [2], which will bring large-scale benefits to individuals and society alike.

The study presents the first example of the critically assessed problem, related to energy efficient design approach in Slovenia, from IEQ point of view. According to the literature review, the presented problem is relevant also in other countries. Although our study was focused on the national legislation status, the recommendations can be applicable in any indoor environment and country with similar practice. In order to achieve healthy, comfortable, stimulating and healing conditions [47], optimal values that reflect in prevented and mastered health risk factors have to be defined. The number of people (e.g. given as a schedule, etc.) as a basic criteria for the building and system design process shall be used. The definition of ventilation rate according to the number of people presents an important step in the design process defined in EN 16798-3 [40], and is required for all sub-holders. All these issues by EN 16798-3 [40] shall be implemented in national legal acts. 


\section{ACKNOWLEDGEMENTS}

The authors acknowledge the financial support from the Slovenian Research Agency (research core funding No. P2-0158, Structural engineering and building physics).

\section{NOMENCLATURES}

$\mathrm{ACH} \quad$ air changes per hour, [1/h]

$A_{\mathrm{du}} \quad$ DuBois body surface area, $\left[\mathrm{m}^{2}\right]$

$A_{\mathrm{z}} \quad$ net occupant floor area of the ventilation zone, $\left[\mathrm{m}^{2}\right]$

$A_{\text {window }}$ window area, $\left[\mathrm{m}^{2}\right]$

$M_{\text {children }}$ metabolic rate of children, [W/ $\left./ \mathrm{m}^{2}\right]$

$U_{\text {floor }}$ thermal transmittance of floor, $\left[\mathrm{W} /\left(\mathrm{m}^{2} \mathrm{~K}\right)\right]$

$U_{\text {roof }}$ thermal transmittance of roof, $\left[\mathrm{W} /\left(\mathrm{m}^{2} \mathrm{~K}\right)\right]$

$U_{\text {window }}$ thermal transmittance of window, $\left[\mathrm{W} /\left(\mathrm{m}^{2} \mathrm{~K}\right)\right]$

$U_{\text {wall }}$ thermal transmittance of wall, $\left[\mathrm{W} /\left(\mathrm{m}^{2} \mathrm{~K}\right)\right]$

$V_{\text {in,d }}$ designed inlet air volume flow, $\left[\mathrm{m}^{3} / \mathrm{h}\right]$

$V_{\text {out }, \mathrm{d}}$ designed outlet air volume flow, $\left[\mathrm{m}^{3} / \mathrm{h}\right]$

$V_{\mathrm{z}} \quad$ zone volume, $\left[\mathrm{m}^{3}\right]$

WWR window to wall ratio, [-]

$\tau_{\text {ao v }} \quad$ glass visible transmittance, [-]

\section{REFERENCES}

[1] Directive (EU) 2018/844 of the European Parliament and of the Council of 30 May 2018 amending Directive 2010/31/ $E U$ on the energy performance of buildings and Directive 2012/27/EU on energy efficiency.

[2] Directive 2012/27/EU of the European Parliament and of the Council of 25 October 2012 on energy efficiency, amending Directives 2009/125/EC and 2010/30/EU and repealing Directives 2004/8/EC and 2006/32/EC.

[3] Energy Act (2015). Official Gazette of the Republic of Slovenia, no. $17 / 14,81 / 15$.

[4] Rules on the ventilation and air-conditioning of building (2002). Official Gazette of the Republic of Slovenia, no. 42/02 with changes. (in Slovene)

[5] Seppänen, O.A., Fisk, W.J., Mendell, M.J. (1999). Association of ventilation rates and $\mathrm{CO}_{2}$ concentrations with health and other responses in commercial and institutional buildings. Indoor Air, vol. 9, no. 4, p. 226-252, Dol:10.1111/j.16000668.1999.00003.x.

[6] Araújo-Martins, J., Carreiro Martins, P., Viegas, J., Aelenei, D., Cano, M.M., Teixeira, J.P., Paixão, P., Papoila, A.L., Leiria-Pinto, P., Pedro, C., Rosado-Pinto, J., Annesi-Maesano, I., Neuparth, N. (2014). Environment and Health in Children Day Care Centres (ENVIRH) - Study rationale and protocol. Revista Portuguesa de Pneumologia (English Edition), vol. 20, no. 6, p. 311-323, D0I:10.1016/j.rppneu.2014.02.006.

[7] Mainka, A., Zajusz-Zubek, E. (2015). Indoor air quality in urban and rural preschools in Upper Silesia, Poland: Particulate matter and carbon dioxide. International Journal of
Environmental Research and Public Health, vol. 12, no. 7, p. 7697-7711, DOl:10.3390/ijerph120707697.

[8] Butala, V., Novak, P. (1999). Energy consumption and potential energy savings in old school buildings. Energy and Buildings, vol. 29, no. 3, p. 241-246, Dol:10.1016/503787788(98)00062-0.

[9] Dovjak, M., Pajek, L. (2016). Childcare - the role of comfort conditions in kindergartens, in-situ analysis and proposed measures. Institute of Public and Environmental Health, $\mathrm{p}$. 1-14. (in Slovene)

[10] Deng, W.-J., Zheng H.-L., Tsui, A.K.Y., Chen, X.-W. (2016). Measurement and health risk assessment of PM2.5, flame retardants, carbonyls and black carbon in indoor and outdoor air in kindergartens in Hong Kong. Environment International, vol. 96, p. 65-74, Dol:10.1016/j.envint.2016.08.013.

[11] Hwang, S.H., Seo, S.C., Yoo, Y., Kim, K.Y., Choung, J.T., Park, W.M. (2017). Indoor air quality of daycare centers in Seoul, Korea. Building and Environment, vol. 124, p. 186-193, DOl:10.1016/j.buildenv.2017.07.042.

[12] Villanueva, F., Tapia, A., Lara, S., Amo-Salas, M. (2018). Indoor and outdoor air concentrations of volatile organic compounds and NO2 in schools of urban, industrial and rural areas in Central-Southern Spain. Science of the Total Environment, vol. 622-623, p. 222-235, D0l:10.1016/j.scitotenv.2017.11.274.

[13] Miri, M., Alahabadi, A., Ehrampoush, M.H., Ghaffari, H.R., Sakhvidi, M.J.Z., Eskandari, M., Rad, A., Lotfi, M.H., Sheikhha, M.H. (2018). Environmental determinants of polycyclic aromatic hydrocarbons exposure at home, at kindergartens and during a commute. Environment International, vol. 118, p. 266-273, DOI:10.1016/j.envint.2018.06.006.

[14] BPIE, Buildings Performance Institute Europe (2011). Europe's Buildings under the Microscope. A country-by-country review of the energy performance of buildings, from http://bpie. eu/publication/europes-buildings-under-the-microscope/, accessed on 15.10.2018.

[15] Česen, M., Urbančič, A., Lah, P. (2008) Energy use in the public sector, its costs and environmental impacts, from https:// www.stat.si/StatisticniDnevi/Docs/Radenci\%202012/ prispevki/Cesen_RabaEnergijeEmisijeStroskiJS-Prispevek_ V2.pdf, accessed on 15.10.2018.

[16] NYSERDA, New York State Energy Research and Development Authority (2018). Evaluation of increased ventilation rates and energy conservation measures at Four New York State Schools, from https://www.nyserda.ny.gov/About/ Publications/EA-Reports-and-Studies/Energy-EfficiencyServices-Reports, accessed on 12.10.2018.

[17] Ben-David, T., Rackes, A., Waring, M.S. (2018). Simplified daily models for estimating energy consumption impacts of changing office building ventilation rates. Building and Environment, vol. 127, p. 250-255, Dol:10.1016/j. buildenv.2017.11.002.

[18] Hekmat, D., Feustel, H.E., Modera, M.P. (1986). Impacts of ventilation strategies on energy consumption and indoor air quality in single-family residences. Energy and Buildings, vol. 9, no. 3, p. 239-251, Dol:10.1016/0378-7788(86)90024-1.

[19] Deng ,Y., Feng, Z., Fang, J., Cao, S.-J. (2018). Impact of ventilation rates on indoor thermal comfort and energy efficiency 
of ground-source heat pump system. Sustainable Cities and Society, vol. 37, p. 154-163, D0l:10.1016/j.scs.2017.11.014.

[20] Aflaki, A., Hirbodi, K., Mahyuddin, N., Yaghoubi, M., Esfandiari, M. (2019). Improving the air change rate in high-rise buildings through a transom ventilation panel: A case study. Building and Environment, vol. 147, p. 35-49, D0l:10.1016/j. buildenv.2018.10.011.

[21] DEPA, Danish Environmental Protection Agency. (2016). Emission of Formaldehyde from Furniture, from $h t$ tps://www2. mst.dk/Udgiv/publications/2016/01/978-87-93435-12-4. pdf, accessed on 2018-03-01.

[22] NIST (2017). National Institute of Standards and Technology. CONTAM Software, from https://www.nist.gov/servicesresources/software/contam, accesed on 2018-03-01.

[23] Persily, A., de Jonge, L. (2017). Carbon dioxide generation rates for building occupants. Indoor Air, vol. 27 , no. 5, p. 868879, Dol:10.1111/ina.12383.

[24] Yun, H., Nam, I., Kim, J., Yang, J., Lee, K., Sohn, J. (2014). A field study of thermal comfort for kindergarten children in Korea: An assessment of existing models and preferences of children. Building and Environment, vol. 75, p. 182-189, DOl:10.1016/j.buildenv.2014.02.003.

[25] Dovjak, M, Košir, M, Kristl, Ž. (2014). Integral interventions for improved indoor air quality in energy efficient kindergartens. 24th Scientific Conference on Energy and the Environment, vol. 5, p. 261-270.

[26] Pirc, J. (2014). Study of indoor air quality in prefabricated and classically built kindergarten. University of Ljubljana, Faculty of Civil and Geodetic Engineering, p. 1-104.

[27] EN 13986:2004. Wood-based panels for use in construction - Characteristics, evaluation of conformity and marking. International Organization for Standardization, Geneva.

[28] EN 717-1:2004. Wood-based panels - Determination of formaldehyde release - Part 1: Formaldehyde emission by the chamber method. International Organization for Standardization. Geneva.

[29] EN 15251:2007. Indoor environmental input parameters for design and assessment of energy performance of buildingsaddressing indoor air quality, thermal environment, lighting and acoustics. International Organization for Standardization, Geneva.

[30] ANSI/ASHRAE Standard 62.1:2004. Ventilation for acceptable indoor air quality. ASHARE, Atlanta.

[31] WHO, World Health Organization. (2010). Formaldehyde. Selected pollutants. WHO Guidelines for Indoor Air Quality. WHO, Regional Office for Europe, Copenhagen, p. 103-156.

[32] NIOSH, National Institute for Occupational Safety and Health. (2010). NIOSH Pocket Guide to Chemical Hazards. CDC, Atlanta.

[33] EnergyPlus(2018). EnergyPlus 8.0.0., from: https:// energyplus.net/features, accessed on2018-01-08.

[34] Földváry, V., Bekö, G., Langer, S., Arrhenius, K., Petráš, D. (2017). Effect of energy renovation on indoor air quality in multifamily residential buildings in Slovakia. Building and Environment, vol. 122, p. 363-372, D0I:10.1016/j. buildenv.2017.06.009.
[35] WHO, World Health Organisation. (2016). Household air pollution and health, from http://www.who.int/mediacentre/ factsheets/fs292/en/, accessed on 2018-03-01.

[36] Bakó-Biró, Z., Clements-Croomea, D.J, Kochhara, N., Awbia, H.B., Williams, M.J. (2007). Ventilation rates in schools and learning performance. Proceedings of the 9th REHVA World Congress: Clima 2007 Wellbeing Indoors, p. 1-19.

[37] Commission Directive 2001/58/EC of 27 July 2001 amending for the second time Directive 91/155/EEC defining and laying down the detailed arrangements for the system of specific information relating to dangerous preparations in implementation of Article 14 of European Parliament and Council Directive 1999/45/EC and relating to dangerous substances in implementation of Article 27 of Council Directive 67/548/EEC (safety data sheets).

[38] ANSI/ASHRAE Standard 62.1:2010. Ventilation for Acceptable Indoor Air Quality. ASHARE, Atlanta.

[39] Report on the Consensus Workshop on Formaldehyde. (1984). Environmental Health Perspective, vol. 58, p. 323-81.

[40] EN 16798-3:2017. Energy performance of buildings - Ventilation for buildings - Part 3: For non-residential buildings - Performance requirements for ventilation and room-conditioning systems. International Organization for Standardization, Geneva.

[41] SIST CR 1752:1999. Ventilation for buildings - Design criteria for the indoor environment. International Organization for Standardization, Geneva.

[42] Carrer, P., Wargocki, P., Fanetti, A. (2015). Can we establish relationship between outdoor air ventilation and health based on the published epidemiological data? Proceedings of the

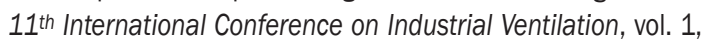
p. 62-69.

[43] Hudobivnik, B., Pajek, L., Kunič, R., Košir, M. (2016). FEM thermal performance analysis of multi-layer external walls during typical summer conditions considering high intensity passive cooling. Applied Energy, vol. 178, p. 363-375, DOI:10.1016/j.apenergy.2016.06.036.

[44] Prek, M., Butala, V. (2012). An enhanced thermal comfort model based on the exergy analysis approach. International Journal of Exergy, vol. 10, no. 2, p. 190-208, Dol:10.1504/ IJEX.2012.045865.

[45] Stritih, U., Koželj, R. (2017). Materials and numerical analysis of thermochemical seasonal solar energy storage for building thermal comfort applications: a review. Research Journal of Environmental Sciences, vol. 11, no. 4, str. 177-191, DOl:10.3923/rjes.2017.177.191.

[46] Thapa, R., Rijal, H.B., Shukuya, M. (2018). Field study on acceptable indoor temperature in temporary shelters built in Nepal after massive earthquake 2015. Building and Environment, vol. 135, p. 330-343, D0l:10.1016/j. buildenv.2018.03.001.

[47] Dovjak, M., Shukuya, M., Krainer, A. (2018). User-centred healing-oriented conditions in the design of hospital environments. International Journal of Environmental Research and Public Health, vol. 15, no. 10, p. 2140, DOI:10.3390/ijerph15102140. 